\title{
Magdalena Rek-Woźniak Badania nad ruchliwością międzypokoleniową: podejścia, konteksty, kontrowersje
}

\section{Research on intergenerational mobility: approaches, contexts, controversies}

The article looks at the existing approaches in the intergenerational mobility research, their axiological foundations, as well as cognitive and practical consequences. In the mainstream sociological debate, as well as wider public debate, intergenerational mobility is assumed to be an adequate indicator of open, democratic society based on the equal opportunities. Most of the research efforts have been focused on identifying main barriers of mobility and main drivers of social advancement. However, in-depth studies reveal the complexity of both individual mobility and structural social fluidity as the phenomena concealing the consequences of growing social polarization. The paper briefly maps the approaches applied in intergenerational mobility research with special focus on questions which still stay understudied in the Polish context.

\begin{tabular}{r|l}
\hline DOI & https://doi.org/10.31268/StudiaBAS.2020.12 \\
\hline Słowa kluczowe & $\begin{array}{l}\text { badania ilościowe, badania jakościowe, ruchliwość } \\
\text { międzypokoleniowa, równość szans, sprawiedliwe społeczeństwo, } \\
\text { struktura społeczna w Polsce }\end{array}$ \\
\hline Keywords & $\begin{array}{l}\text { quantitative research, qualitative research, intergenerational mobility, } \\
\text { equal opportunities, just society, social structure in Poland }\end{array}$ \\
\hline O autorce & $\begin{array}{l}\text { doktor nauk humanistycznych, Katedra Socjologii Struktur i Zmian } \\
\text { Społecznych, Wydział Ekonomiczno-Socjologiczny, Uniwersytet } \\
\text { Łódzki } \bullet \text { magdalena.rek@uni.lodz.pl } \\
\text { ORCID 0000-0002-4526-5374 }\end{array}$ \\
\hline
\end{tabular}

\section{Wstęp}

Ruchliwość (mobilność) międzypokoleniowa stanowi jeden z kluczowych punktów odniesienia w dyskusji na temat rosnących nierówności społeczno-ekonomicznych. W opublikowanym w październiku 2018 r. przez OECD raporcie zatytułowanym A Broken Social Elevator? How to Promote Social Mobility ${ }^{1}$ wskazano na powszechne występowanie zjawisk „lepkiej podłogi” i „lepkiego sufitu", tj. dziedziczenia zarówno najniższych, jak i najwyższych pozycji społecznych, co ma stanowić zaprzeczenie zasady równości szans. Ta z kolei jest punktem odniesienia dla polityk publicznych formułowanych na różnych szczeblach. Nawiązania do niej można znaleźć w dokumentach unijnych, zwłaszcza dotyczących edukacji i rynku pracy. W Wielkiej Brytanii podniesienie wskaźników ruchliwości międzypokoleniowej stało się przedmiotem ponadpartyjnego konsensusu² a od 2012 r. przy tamtejszym Departamencie ds. Edukacji działa Komisja ds. Mobilności Społecznej³.

1 OECD, A Broken Social Elevator? How to Promote Social Mobility, OECD Publishing, 2018, https://doi.org/10.1787/ 9789264301085-en. Raport powstał jako czwarty w serii, którą zapoczątkował Growing unequal z 2008 r.

2 G. Payne, A New Social Mobility? The political redefinition of a sociological problem, "Contemporary Social Science" 2012, vol. 7, no. 1, https://doi.org/10.1080/21582041.2011.652360.

3 W 2012 r. Komisję ds. Biedy wśród Dzieci przemianowano na Komisję ds. Mobilności Społecznej i Biedy wśród Dzieci. Od 2016 r. nosi nazwę Komisji ds. Mobilności Społecznej. 
W Polsce po 1989 r. ruchliwość międzypokoleniowa nie zyskała wprawdzie tak jednoznacznie eksponowanego miejsca jako priorytet w agendzie politycznej, ale hasło "równych szans" na stałe weszło do debaty politycznej i medialnej ${ }^{4}$ Jest to związane z przeświadczeniem, że ruchliwość społeczna stanowi czynnik ograniczający negatywne konsekwencje nierówności społecznych. Nie tylko redukuje zakres międzygeneracyjnego dziedziczenia pozycji, ale także pozwala utrzymać wiarę w merytokratyczny charakter mechanizmów społecznej selekcji ${ }^{5}$. Jest więc kluczowym wskaźnikiem sprawiedliwego ładu, w którym wszystkie obywatelki i wszyscy obywatele mają równe szanse na zrealizowanie pełni swojego potencjału. To z kolei ma przyczyniać się do zwiększania efektywności systemu gospodarczego oraz minimalizować ryzyko wycofywania akceptacji systemu politycznego.

Intelektualnym zapleczem tego typu dyskursu, określanego przez brytyjskiego socjologa Sama Friedmana „celebracyjnym" ${ }^{\prime 6}$, był główny nurt badań socjologicznych i ekonomicznych dotyczących doskonalenia statystycznych pomiarów ruchliwości i sporów wokół ich wyników. Jednocześnie przez kilka dekad marginalizowano te nurty refleksji i badań, które dążą do zrozumienia ludzkich doświadczeń związanych z położeniem społecznym i jego zmianami w kontekście grupowych tożsamości oraz interesów. Obserwowany w ostatnich latach wzrost ich popularności wydaje się odpowiedzią na rosnące rozwarstwienie i napięcia we współczesnych społeczeństwach. Wyniki tych badań skłaniają jednocześnie do rozważenia tezy, że samo udrożnienie kanałów awansu dla osób utalentowanych nie wystarczy do utrzymania stabilności ładu społeczno-politycznego.

W zarysowanym powyżej kontekście należy stwierdzić, że niniejszy artykuł ma trzy cele: krótką rekapitulację refleksji naukowej nad ruchliwością międzypokoleniową; zaprezentowanie podejść dominujących w badaniach nad ruchliwością międzypokoleniową w odniesieniu do ideologicznych sporów towarzyszących zmianom społecznym; omówienie powyższych zagadnień w odniesieniu do polskich realiów, w tym krytyczne omówienie badań własnych autorki nad ruchliwością międzypokoleniową młodych dorosłych w okresie transformacji systemowej.

\section{Ruchliwość międzypokoleniowa a społeczeństwo dobrze urządzone. 0 uwikłaniu nauk społecznych raz jeszcze}

Dyskusję na temat znaczenia i funkcji ruchliwości społecznej można, jak sugeruje Henryk Domański, sprowadzić do trzech fundamentalnych zagadnień: czy i w jaki sposób zjawisko to oddziałuje na formowanie się struktury społecznej (a więc: czy i w jaki sposób wpływa na ostrość dystansów i barier społecznych lub z nich wynika), jakie są polityczne konsekwencje

4 W. Woźniak, Nierówności społeczne w polskim dyskursie politycznym, Wydawnictwo Naukowe Scholar, Warszawa 2012.

5 J.H. Goldthorpe, M. Jackson, Intergenerational class mobility in contemporary Britain: political concerns and empirical findings. British Journal of Sociology " "The British Journal of Sociology” 2008, vol. 58, no. 4, https:// doi.org/10.1111/j.1468-4446.2007.00165.x.

6 S. Friedman, The Price of the Ticket: Rethinking the Experience of Social Mobility, "SSociology” 2014, vol. 48, no.2, https://doi.org/10.1177/0038038513490355. 
dominacji w danym społeczeństwie określonych kryteriów dostępu do pozycji społecznych (a więc: czy istnieje związek pomiędzy ruchliwością społeczną a stabilnością systemu politycznego i jaka jest natura tego związku) i - wreszcie - jak zmiana pozycji społecznej oddziałuje na funkcjonowanie ludzi w różnych wymiarach: stylów życia, sposobów myślenia i działania (a więc jakie są psychologiczne konsekwencje ruchliwości)?. Wszystkie te kwestie są rozważane także na płaszczyźnie aksjologicznej. O ruchliwości międzypokoleniowej mówi się w odniesieniu do dwóch zasad - równości szans i równości wyniku (warunków życia). Z tą pierwszą wiążą się postulaty tworzenia jednakowo korzystnych dla wszystkich warunków „na starcie” i zgoda na zróżnicowanie pozycji „na mecie”. W kontekście ruchliwości wewnątrz struktury społeczno-ekonomicznej jest ona najczęściej łączona z postulatami niedyskryminacji ze względu na cechy przypisane, takie jak pochodzenie społeczne, etniczne, rasowe czy płeć. Dostęp do pozycji społecznej powinien być determinowany indywidualnymi predyspozycjami i osiągnięciami. Dążenie do równości wyniku oznacza z kolei niwelowanie nierówności w dochodach i jakości życia ludzi. Ewentualne interwencje w przebieg procesu dziedziczenia położenia społecznego powinny więc być zorientowane nie tyle na zapewnienie dzieciom z rodzin o niskim statusie możliwości awansu, ile na zmniejszenie przepaści dzielących ludzi znajdujących się na różnych szczeblach społecznej drabiny. Obie zasady są rozpatrywane i dyskutowane w wielu wariantach ${ }^{8}$, jednak egalitarna idea równości warunków życia jest zazwyczaj łączona z wartościami lewicowymi, a pojęcie równości szans jest częściej kojarzone ze światopoglądem liberalnym.

Rozważania odnoszące się do tych zagadnień można znaleźć już u ojców założycieli nauk społecznych, którzy obserwowali formowanie się nowoczesnych społeczeństw. Na przykład Alexis de Tocqueville przekonywał, że źródło szczególnego dynamizmu społeczeństwa amerykańskiego stanowią indywidualne aspiracje do awansu społecznego, związane z brakiem tradycji arystokratycznych i centralną pozycją idei równych szans w krzepnącej amerykańskiej kulturze. Z kolei w ujęciu Karola Marksa ład kapitalistyczny, ufundowany na dominacji klas posiadających nad klasami pracującymi, dąży do samoreprodukcji - te pierwsze będą więc starać się zachować przewagę, blokując aspiracje tych drugich. Trwała zmiana wskazanej relacji jest możliwa tylko w wyniku radykalnego przekształcenia stosunków własności. W pracach Vilfreda Pareto znajdziemy zaś wątki związane z pozytywnym waloryzowaniem mobilności społecznej, jako mechanizmu ułatwiającego cyrkulację elit i stabilizującego tym samym ład polityczny. W II połowie XX w. przeświadczenie, że ruchliwość społeczna ma znaczenie emancypacyjne w wymiarze jednostkowym i modernizacyjne w wymiarze społecznym, stało się milczącym założeniem w debacie o nierównościach społecznych. Aksjomaty te następująco podsumował H. Domański: Ruchliwość - synonim zmiany pozycji - jest charakterystykq otwartości, która pozytywnie kojarzy się z cenionymi wartościami, takimi jak demokracja, innowacyjność czy pluralizm poglądów?

7 H. Domański, O ruchliwości społecznej w Polsce, Wydawnictwo IFiS PAN, Warszawa 2004.

8 Zob. np.:. J. Rawls, Teoria sprawiedliwości, Wydawnictwo Naukowe PWN, Warszawa 1994; A. Sen, Nierówności. Dalsze rozważania, Społeczny Instytut Wydawniczy Znak, Fundacja Stefana Batorego, Kraków-Warszawa 2000; A. Lister, The "Mirage" of Social Justice: Hayek Against (and For) Rawls, "Critical Review" 2013, vol. 25, no. 3-4, https://doi.org/10.1080/08913811.2013.853859; S. White, Równość, Sic!, Warszawa 2003.

9 H. Domański, O ruchliwości społecznej w Polsce, op. cit., s. 13. 
Polityczna klęska socjalizmu jako doktryny formalnie zakotwiczonej w światopoglądzie egalitarnym ułatwiła także zwycięstwo hasła „równości szans" i dominację przeświadczenia, że merytokratyczne zasady alokacji jednostek w strukturze są właściwie synonimem sprawiedliwego ładu ${ }^{10}$, w którym o rozdziale społecznych „nagród” w postaci prestiżu, władzy i zarobków/ majątku (a więc trzech kluczowych wymiarów położenia społecznego) decyduje rynek. W takim układzie istnienie hierarchii społecznych, nawet bardzo wyraźnych, może być uznawane za usprawiedliwione tak długo, jak długo dostęp do dowolnych pozycji jest pochodną indywidualnych „zasług” (talentu, kwalifikacji, zawodowych osiągnięć itd.). Szczególnie chętnie wykorzystywanym akademickim zapleczem takich idei stały się tzw. funkcjonalne teorie uwarstwienia, które od lat 40. XX w. były podstawą amerykańskich analiz mobilności i struktury społecznej. W debacie polityczno-medialnej wciąż powracają np. echa koncepcji Kingsleya Davisa i Wilberta E. Moore'a z 1944 r. ${ }^{11}$, wielokrotnie krytykowanej ze względu na ignorowanie rozmaitych formalnych i nieformalnych barier ${ }^{12}$ utrudniających realizację indywidualnych aspiracji, ale też za naiwne założenia dotyczące jednorodności psychologicznych motywacji do podejmowania starań o zajęcie określonych pozycji społecznych. Towarzysząca równości szans nierówność nagród miała stanowić czynnik motywujący, ale także punkt odniesienia dla ewaluacji ludzkich starań.

Zmierzch epoki przemysłowej wiązał się z kolei ze zwrotem w stronę "sektorów opartych na wiedzy", jako kluczowych dla dalszego rozwoju społeczno-ekonomicznego. Michael Young, autor pojęcia merytokracji, z perspektywy kilku dekad zwracał uwagę na niepokojące konsekwencje przyjęcia tej zasady jako synonimu sprawiedliwości społecznej. Po pierwsze, skierowanie wysiłków zarówno jednostkowych, jak i systemowych w stronę formalnej edukacji jako najważniejszego kanału dostępu do wyższych pozycji społecznych (a więc i awansu społecznego) spowodowało, że przymioty innego typu lub niepoddające się łatwemu „pomiarowi” (takie jak dobroć, sumienność czy lojalność) właściwie utraciły wartość. Po drugie, wyraźnie wzmocniło to wiarę ludzi znajdujących się na najbardziej uprzywilejowanych pozycjach, że wszystko zawdzięczają wyłącznie własnemu wysiłkowi (nawet jeśli w praktyce ich sytuacja jest efektem dziedzicznego przywileju) i w związku z tym zasługują na wszystko, co otrzymują ${ }^{13}$.

\section{Ruchliwość międzypokoleniowa a język opisu struktury społecznej}

Ruchliwość międzypokoleniową mierzy się, porównując wartości zmiennych charakteryzujących położenie społeczno-ekonomiczne rodziców i dzieci. Można do tego wykorzystywać proste wskaźniki pozwalające stosunkowo łatwo odtworzyć przesunięcia w różnych wymiarach

10 Stało się tak wbrew pierwotnemu znaczeniu tego neologizmu, który opisywał fikcyjne społeczeństwo zbudowane wyłącznie na hierarchii wąsko definiowanych talentów i zasług jako dystopijne. Więcej na temat kariery pojęcia i koncepcji merytokracji w debacie naukowej i politycznej można przeczytać w: W. Woźniak, Użycie i nadużycie nauk społecznych. Przypadek merytokracji [w:] Wiedza, władza, ideologia. O społecznej funkcji uniwersytetu w społeczeństwie rynkowym, Wydawnictwo Naukowe Scholar, Warszawa 2012.

11 K. Davis, W.E. Moore, O niektórych zasadach uwarstwienia [w:] Socjologia. Lektury, Znak, Kraków 2005.

12 W. Wesołowski, Klasy, warstwy, władza, PWN, Warszawa 1974.

13 W. Woźniak, Użycie i nadużycie nauk społecznych, op. cit. 
hierarchii społecznej, takie jak poziom dochodów czy wykształcenia. W naukach społecznych konstruuje się też bardziej złożone wskaźniki położenia społecznego, identyfikowane z podziałem warstwowym lub klasowym. Badania struktury społecznej mają dwóch ikonicznych patronów - K. Marksa i Maxa Webera, jednak to ten drugi uchodzi za promotora badań nad ruchliwością społeczną. Kluczową dla tych badań tezę o zasadniczej roli mobilności w procesie formowania się nowoczesnych społeczeństw ujął następująco: [...] klasy społeczne to wszystkie położenia klasowe, między którymi przechodzenie osobiste w kolejnych pokoleniach jest całkowicie możliwe i zwykle (typowo) występuje ${ }^{14}$. Badania nad szansami życiowymi dzieci w zależności od położenia rynkowego rodziców stanowią więc integralny element weberowskiej agendy analiz klasowych. Bardzo istotne okazało się też w ich kontekście założenie o wzroście roli czynników umożliwiających osiąganie pozycji w stosunku do cech askryptywnych (przypisanych), co z kolei miało stanowić wyraz postępującej racjonalizacji życia społecznego. Tezy o strukturotwórczej funkcji ruchliwości społecznej można znaleźć też u Pitirima Sorokina ${ }^{15}$, podobnie jak założenie, że nie istnieją społeczeństwa doskonale „zamknięte”, wolne od mobilności, a całości społeczne można klasyfikować w zależności od natężenia i charakterystyki procesów ruchliwości, które w ich obrębie zachodzą.

Kolejne konceptualizacje ruchliwości społecznej były w znacznym stopniu związane z licznymi projektami badawczymi, które intensywnie prowadzono od końca lat 40. XX w. i które stały się swoistą wizytówką współczesnej socjologii empirycznej, a zwłaszcza jej nurtu ilościowego. Ożywionej debacie metodologicznej związanej z doskonaleniem analiz statystycznych prowadzonych na dużych, reprezentatywnych próbach towarzyszyło jednak stopniowe ograniczanie sporów teoretycznych. W ramach studiów nad ruchliwością często niemal milcząco przyjmowano bowiem podobne założenia na temat zasad porządku społecznego ${ }^{16}$.

Dominujący (mimo iż pojawiały się też liczne polemiki) przez kilka dziesięcioleci kanon socjologicznych badań w tym obszarze kształtował się od lat 60. do 80. XX w. Jest kojarzony przede wszystkim z pracami Johna Goldthorpe’a - autora i współautora fundamentalnych prac na temat powojennych przemian struktury społeczeństwa brytyjskiego, na czele z projektem badawczym Nuffield Mobility Study, a także opracowań porównawczych, takich jak wydana w 1992 r. wraz z Robertem Eriksonem książka The Constant Flux. Industrial Society and Social Mobility ${ }^{17}$. Podstawę tego podejścia stanowi metodologiczny indywidualizm, tj. założenie, że zrozumienie i opis zjawisk społecznych są możliwe jedynie dzięki badaniu działań jednostek ${ }^{18}$. Badacze ci osadzili ruchliwość w koncepcji, którą nazwali „liberalną teorią industrializmu”. „Liberalizm” oznacza tu po prostu polityczne warunki brzegowe, w których zachodzą procesy kształtujące strukturę

14 M. Weber, Gospodarka i społeczeństwo, Wydawnictwo Naukowe PWN, Warszawa 2002, s. 228.

15 P. Sorokin, Ruchliwość społeczna, Wydawnictwo IFiS PAN, Warszawa 2009.

16 D.B. Grusky, K.A. Weeden, Does the Sociological Approach to Studying Social Mobility Have a Future [w:] Mobility and Inequality: Frontiers of Research From Sociology and Economics, Stanford University Press, Stanford 2006, s. 85.

17 R. Erikson, J.H. Goldthorpe, The Constant Flux. A Study of Class Mobility in Industrial Societies, Clarendon Press, Oxford 1992.

18 Ibidem, s. 1. 
społeczną w krajach zachodnich i które można hasłowo opisać jako demokratyczny pluralizm. Z kolei wewnętrzna logika systemu przemysłowego miała prowadzić do konwergencji ścieżek rozwojowych poszczególnych społeczeństw. Dla ukształtowania dominującego sposobu myślenia o ruchliwości społecznej kluczowe były też następujące trzy założenia: w społeczeństwach przemysłowych wskaźniki ruchliwości są w porównaniu z wcześniejszymi formacjami społecznymi generalnie wysokie, a liczba przypadków awansu społecznego dominuje nad liczbą degradacji; szanse na ruchliwość społeczną są relatywnie wyrównane, a więc ludzie wywodzący się z różnych segmentów struktury konkurują o pożądane pozycje na równiejszych zasadach; wzrastają zarówno wskaźniki ruchliwości, jak i równość szans.

Zgodnie z zasadami tego nurtu ruchliwość absolutną, która może być rezultatem zmieniającej się liczebności kategorii konstruujących strukturę społeczną w pokoleniach rodziców i dzieci, przeciwstawia się ruchliwości względnej, czyli oszacowaniu odsetka ludzi, którzy znaleźli się w innej klasie społecznej niż ta, z której się wywodzą. Dopiero ten drugi rodzaj ruchliwości daje podstawową informację na temat stopnia otwartości struktury społecznej. Ten ujawniający się w analizie danych empirycznych paradoks stał się podstawą wielu późniejszych analiz, prowadzonych nawet przez tych badaczy, którzy formalnie pozostawali poza omawianą szkołą, ale zawsze podejmowali dialog z jej przedstawicielami ${ }^{19}$. Kontrolowanie zmian ruchliwości związanych z przekształceniami struktury zawodowej ${ }^{20}$ pozwoliło też na dokonywanie porównań zarówno w czasie, jak i w wymiarze międzynarodowym. Pozytywnym skutkiem tych badań było pokazanie, że choć powojenna transformacja ładu społeczno-ekonomiczno-politycznego w krajach zachodnich przyniosła wzrost wskaźników ruchliwości absolutnej, wskaźniki mobilności względnej pozostały w nich na niezmienionym poziomie. Już w latach 70. otwartość struktury brytyjskiego społeczeństwa okazała się więc w znacznej mierze iluzją. Podobne wnioski płyną z międzynarodowych badań porównawczych, których wyniki wykazały istnienie współzależności pomiędzy poziomem nierówności społeczno-ekonomicznych a wysokością wskaźników ruchliwości międzypokoleniowej w różnych wymiarach. Przykładowo okazało się, że amerykańskie społeczeństwo, z jego fundacyjną mitologią awansu społecznego, w praktyce oferuje swoim obywatelkom i obywatelom mniejsze możliwości w tym zakresie niż np. kraje skandynawskie ${ }^{21}$.

Tak zarysowaną agendę badawczą cechowały jednak ograniczenia, wynikające chociażby z doboru populacji objętych badaniem - przez lata byli to wyłącznie mężczyźni w wieku produkcyjnym, których pozycje zestawiano z pozycjami ojców. Znacznie mniej uwagi poświęcono też problemom indywidualnych i grupowych doświadczeń ruchliwości społecznej, a także

19 Takich jak: Peter Saunders, Fiona Devine, Trevor Noble, Muriel Egerton czy David Grusky i Kim Weeden.

20 Poprzez stosowanie zabiegów matematycznych opartych na tzw. modelu doskonałej ruchliwości (perfect mobility model), pozwalających na szacowanie „czystej” ruchliwości między kategoriami. Zob. H. Domański, Struktura społeczna, Wydawnictwo Naukowe Scholar, Warszawa 2007, s. 200.

21 Zob. np. F.F. Hertel, O. Groh-Samberg, The Relation between Inequality and Intergenerational Class Mobility in 39 Countries, „American Sociological Review” 2019, vol. 84, no. 6, https://doi.org/10.1177/0003122419885094. W tej dyskusji pojawiają się jednak także argumenty na rzecz tezy o stale niskim poziomie ruchliwości społecznej i idące za tym postulaty rozdzielenia refleksji nad nierównościami społecznymi i nad ruchliwością społeczną. Zob. np. G. Clark, The Son Also Rises. Surnames and the History of Social Mobility, Princeton University Press, Princeton 2014, https://doi.org/10.1515/9781400851096. 
przeżywania napięć i konfliktów, które towarzyszą głębokim przemianom struktury społecznej, np. awansu lub degradacji całych jej segmentów. Kwestie te zostały podjęte w dwóch pracach J. Goldthorpe'a. Pierwsza z nich to The Affluent Worker - seria książek z lat 1968 i 1969, których był współautorem. Dotyczyły przemian świadomości i tożsamości klasowej zachodzących wraz z procesem „burżuazyjnienia klasy robotniczej” po II wojnie światowej. Druga praca to rozdział zamieszczony w książce Social Mobility and Class Structure in Modern Britain, oparty na analizie autobiograficznych notatek mężczyzn doświadczających ruchliwości społecznej. W tekstach tych wskazano, że nawet tych, którzy w porównaniu z własnymi ojcami nie dokonali istotnych przesunięć na drabinie społeczno-zawodowej, charakteryzowało poczucie kolektywnego awansu związane z generalną poprawą warunków pracy i płacy, a także jakości życia. Bardzo klarowny był też przekaz dotyczący zmiany stosunków pracy w wyniku działania związków zawodowych, o czym wspominał biorący udział w badaniu zecer: Władza przesunęła się ze strony pracodawcy w stronę pracownika, ze znacznie silniejszymi zwiq̨zkami zawodowymi, które nie boją się używać swojej władzy. [...] Dzieci, które teraz kończq̨ szkoły, sq̨ lepiej wykształcone i nie pozwoliłyby sobie na życie w warunkach, w jakich żył mój ojciec ${ }^{22}$. Jednocześnie respondenci, którzy awansowali w wymiarze indywidualnym, zazwyczaj odnosili się do pojawienia się nowych możliwości - szans, których ich ojcowie nie mieli. Te wyniki skłoniły J. Goldthorpe’a do wzmocnienia wniosków na temat jednoznacznie pozytywnej roli ruchliwości międzypokoleniowej w przekształcaniu skostniałego brytyjskiego systemu klasowego.

Powyższe tezy nie były jednak, jak przekonuje np. S. Friedman, dostatecznie ugruntowane empirycznie. Większość awansujących mężczyzn objętych badaniem zasiliła bowiem nowopowstające segmenty klas średnich, w których otoczeni przez podobnych sobie "nowicjuszy” nie musieli się mierzyć z poczuciem obcości i nieznajomości reguł gry w skonsolidowanym, uprzywilejowanym środowisku społecznym. Zarówno bardzo niski poziom realizacji próby, jak i sposób skonstruowania narzędzia (instrukcja do napisania notatki autobiograficznej w oparciu o osiem ustrukturyzowanych pytań) mogły sprzyjać pomijaniu czy niedoszacowaniu zjawisk, które nie interesowały zespołu projektowego. Przegląd cytatów zamieszczonych w oryginalnym tekście pozwala jednak dostrzec w wypowiedziach niektórych respondentów ślady ambiwalencji czy poczucia obcości w nowym środowisku społecznym. Na temat powodów, dla których nie zostały one jednak poddane pogłębionej analizie ${ }^{23}$, można jedynie spekulować. W przypadku wybitnego socjologa, którego ilościowe analizy cechowała analityczna przenikliwość, tego typu przeoczenie można wiązać z niedocenianiem wagi badań jakościowych, a także z faktem, że uzyskany wynik doskonale wpisywał się w fundamentalne założenia dotyczące roli ruchliwości społecznej w stabilizowaniu i jednocześnie przekształcaniu porządku społecznego.

Dominacja ilościowych badań, ukierunkowanych przede wszystkim na identyfikowanie głównych kierunków przemieszczeń w strukturze społeczno-zawodowej i poszukiwanie wzorów dystrybucji szans mobilności w zależności od punktu „startu”, współgrała z wieloletnią marginalizacją refleksji skupionej wokół tzw. relacyjnych aspektów struktury społecznej - grupo-

22 J.H. Goldthorpe, C. Llewellyn, The Experience of Social Mobility [w:] Social Mobility and Class Structure in Modern Britain, Clarendon Press, Oxford (UK) 1980, s. 231.

23 S. Friedman, op. cit. 
wych tożsamości, interesów, stosunków dominacji i podporządkowania, a także indywidualnych doświadczeń związanych z pozycją społeczną i jej zmianami. Osoby awansujące w wymiarze wykształcenia, zawodu czy zarobków mogą się nigdy nie doczekać akceptacji ze strony środowisk, do których wchodzą, a jednocześnie borykać się z poczuciem zdrady i winy wobec klasy pochodzenia. Z kolei ludzie doświadczający deklasacji mogą bronić się przed pełną integracją towarzysko-środowiskową w klasie „dojścia”, ponieważ potwierdzałaby ona ostatecznie ich społeczną degradację. Jednocześnie będą przy tym doświadczać niepewności w (słabnących) kontaktach z kręgami społecznymi, z których się wywodzą. Ponadto sposób, w jaki ludzie przeżywają i interpretują swoje doświadczenie mobilności, może być silnie zróżnicowany ze względu na inne cechy społeczno-demograficzne, takie jak: płeć, pochodzenie etniczno-rasowe czy geograficzne.

W socjologii nie jest to perspektywa nowa. Na skomplikowaną naturę ruchliwości społecznej zwracali uwagę zarówno ojciec założyciel dyscypliny Émile Durkheim, jak i P. Sorokin, autor pierwszej teoretycznej rozprawy poświęconej temu zjawisku, wydanej w 1927 r. Badacze, którzy podejmują podobne wątki, koncentrują się przede wszystkim na mechanizmach sprzyjających reprodukcji struktury społecznej. Inspirację dla nich mogły stanowić - pierwszy tom Kapitału i rozwinięta przez późniejszych interpretatorów myśli K. Marksa idea, że każdy sposób produkcji jest tak skonstruowany, by się samoreprodukować, a także rozważania M. Webera na temat relacji pomiędzy klasą społeczną a statusem społecznym. Szczególnie warta wspomnienia wydaje się w tym kontekście książka Richarda Senneta i Jonathana Cobba The Hidden Injuries of Class. Choć doświadczenie awansu i degradacji społecznej nie jest jej głównym tematem, w opracowanych przez autorów wywiadach z robotnikami powraca motyw „urazów” (injuries) jako emocjonalnych skutków funkcjonowania w społeczeństwie, które wartość człowieka utożsamia z jego zdolnością do zdobycia wyższego wykształcenia i adekwatnej pozycji zawodowej. Taka fetyszyzacja mobilności społecznej oraz aspiracji do indywidualnego awansu może jednak mieć negatywne konsekwencje dla poczucia godności zarówno tych, którzy go nie osiągają, jak i tych, którym się to udaje.

Najbardziej znane współcześnie rozwinięcie powyższych zagadnień łączy się z nazwiskiem Pierre'a Bourdieu, który stosując metaforę kapitałów ekonomicznego, społecznego i kulturowego, określił płaszczyzny porządku społecznego opartego na dominacji jednych klas nad drugimi. Szczególnie ważne są przy tym mechanizmy odnawiania się hierarchii poprzez style życia czy „smak" estetyczny oraz mechanizmy tzw. przemocy symbolicznej, ujawniające się w działaniach m.in. systemu edukacji ${ }^{24}$ i reprodukujące uprzywilejowanie elit poprzez zniechęcanie dzieci z klas ludowych do podejmowania starań o zajęcie bardziej uprzywilejowanych społecznie pozycji $i^{25}$. Badacz w różnych pracach ${ }^{26}$ wracał przy tym do wątku bolesnego stanu zawieszenia

24 Analizy nieformalnych reguł działania systemu edukacji i polityk edukacyjnych jako instytucji działających często wbrew oficjalnym celom (tj. szerokiej emancypacji społecznej) w interesie klas dominujących stanowią osobne, szerokie pole analiz, którego omówienie przekracza ramy tego opracowania.

25 P. Bourdieu, J.C. Passeron, Reprodukcja. Elementy teorii systemu nauczania, Wydawnictwo Naukowe PWN, Warszawa 2006.

26 P. Bourdieu, La Noblesse d'État. Grandes écoles et esprit de corps, Minuit, Paris 1993; P. Bourdieu, Dystynkcja. Społeczna krytyka władzy sq̨dzenia, Wydawnictwo Naukowe Scholar, Warszawa 2005. 
między segmentami struktury społecznej, który towarzyszy osobom przekraczającym granice środowiska urodzenia ${ }^{27}$. Motyw ten jest krytycznie rozwijany w pracach innych badaczy ${ }^{28}$.

\section{Ruchliwość międzypokoleniowa w agendzie badawczej polskiej socjologii}

Impulsem dla polskich badaczek i badaczy zajmujących się ruchliwością społeczną były - podobnie jak w innych państwach - głębokie przekształcenia porządku społecznego po II wojnie światowej. Ważny nurt debaty, która toczyła się wtedy w polskiej socjologii, dotyczył realizacji idei sprawiedliwości społecznej poprzez masowy awans społeczny, zwłaszcza młodzieży wiejskiej i robotniczej ${ }^{29}$, pobudzany zarówno procesami industrializacji oraz urbanizacji, jak i stworzeniem korzystnych rozwiązań w politykach publicznych, przede wszystkim edukacyjnej. Jednocześnie, zwłaszcza od lat 70., był obecny w niej pierwiastek efektywnościowy, związany z modernizacją struktury społeczno-gospodarczej kraju ${ }^{30}$, a także stabilizacyjny - w publikacjach z lat 80. powracał motyw zablokowania kanałów indywidualnego awansu społecznego jako jednego z kluczowych źródeł kryzysu systemu socjalistycznego ${ }^{31}$. Początkowo dominujące analizy jakościowe oparte głównie na źródłach pamiętnikarskich i zawężone do konkretnych kategorii społecznych oraz prowadzone lokalnie stosunkowo szybko ustąpiły miejsca ogólnopolskim, reprezentacyjnym (choć w pierwszych dekadach, podobnie jak w krajach zachodnich, ograniczonych do mężczyzn) badaniom sondażowym, w których wykorzystywano coraz bardziej zaawansowane analizy statystyczne ${ }^{32}$.

Ścisły w praktyce związek analiz ruchliwości międzypokoleniowej z badaniami przemian struktury społeczno-ekonomicznej miał w tym przypadku także inne konsekwencje. Komentatorzy polskiej naukowej debaty nad strukturą społeczną ${ }^{33}$ zwracają uwagę, że bardzo szybko

27 To ostatnie zresztą było jego własnym doświadczeniem.

28 B. Lahire, L'Homme pluriel. Les ressorts de l'action, Hachette, Paris 2007; S. Friedman, D. Lauriston, The Class Ceiling: Why it Pays to be Privileged, Bristol University Press, Bristol 2019, https://doi.org/10.1590/ s0104-71832019000300018. S. Friedman, krytycznie analizując wyniki BBC Great British Class Survey (GBCS) uzupełnione własnymi badaniami fokusowymi, wykazałnp., że ludzie wywodzący się z klas ludowych nawet po awansie do ekonomicznej elity mają zmniejszone szanse na akumulację kapitału.

29 J. Chałasiński, Awans pokolenia, Ludowa Spółdzielnia Wydawnicza, Warszawa 1964; J. Chałasiński, Drogi awansu społecznego robotnika: studium oparte na autobiografiach robotników, Ludowa Spółdzielnia Wydawnicza, Warszawa 1979; S. Ossowski, Ruchliwość społeczna jako wynik rewolucji społecznej [w:] Dzieła, t. 5, Z zagadnień struktury społecznej, PWN, Warszawa 1968.

30 K. Zagórski, Rozwój, struktura i ruchliwość społeczna, PWN, Warszawa 1978.

31 W. Wesołowski, B.W. Mach, Systemowe funkcje ruchliwości społecznej w Polsce, IFiS PAN, Warszawa 1986.

32 Największym przedsięwzięciem tego typu jest POLPAN - badanie panelowe, realizowane od 1988 r. na próbach ogólnopolskich. Do tej postaci wyewoluowało z tzw. badań szczecińsko-koszalińskich i łódzkich, realizowanych w latach 1964-1994. Zob. np. W. Wesołowski, K. Janicka, K.M. Słomczyński, Struktutralizacja społeczeństwa polskiego. Ewolucja paradygmatu, Wydawnictwo IFiS PAN, Warszawa 2017. Warto odnotować, że w ramach POLPAN-u gromadzi się także materiały biograficzne, które jednak nie podlegają opracowaniu równie systematycznemu jak dane sondażowe.

33 D. Ost, Stuck in the Past and the Future. Class Analysis in Postcommunist Poland, „East European Politics and Societies" 2015, vol. 29, no. 3, https://doi.org/10.1177/0888325415602058. 
zrezygnowano w jej głównym nurcie (utożsamianym z tzw. szkołą warszawską) z marksowskiej optyki na rzecz ujęć utożsamiających klasowość z miejscem w hierarchii społeczno-zawodowej ${ }^{34}$. Znalazły się tam więc ilościowe analizy zarówno zmienności ruchliwości międzypokoleniowej, jak i przepływów między poszczególnymi kategoriami, ze szczególnym uwzględnieniem statystycznych szans znalezienia się w określonym segmencie struktury w zależności od pochodzenia społecznego (mierzonego pozycją społeczno-zawodową rodziców w momencie, kiedy respondent miał ok. 14 lat). Nieliczne prace stanowiły przy tym pogłębione studia poświęcone sytuacji konkretnych kategorii społecznych. Wciąż wyjątkowe pod tym względem pozostaje badanie losów „pokolenia 1989 r.”, czyli osób, które wchodziły w dorosłość w momencie przełomu ustrojowego ${ }^{35}$. Główne pytanie organizujące badania nad ruchliwością prowadzone w tym nurcie dotyczy więc otwartości polskiej struktury społecznej i różnic w zakorzenieniu społecznym ludzi wywodzących się z poszczególnych segmentów struktury społeczno-zawodowej, także w zależności od płci ${ }^{36}$. Podobnie jak w przypadku innych dużych projektów tego typu analizuje się tu korelaty przemieszczeń pozycyjnych, takie jak subiektywna ocena różnych elementów sytuacji życiowej badanych i ich nastawienia wobec rzeczywistości społecznej.

Bardzo ważne dla tych analiz są też - wątek porównawczy związany z modernizacją i westernizacją polskiego społeczeństwa oraz śledzenie procesów rekrutacji do nowych segmentów struktury społecznej (zwłaszcza w kontekście dyskusji o statusie polskiej klasy średniej). Zjawiska międzygeneracyjnej degradacji budziły mniejsze zainteresowanie niż awans, choć we wnioskach z analiz powraca wątek zaniepokojenia wzrostem i utrwalaniem polaryzacji społecznej, które w pracach zespołu Kazimierza M. Słomczyńskiego były wiązane z tezami o „pękniętej strukturze polskiego społeczeństwa” oraz o działaniu w nim „efektu św. Mateusza" ${ }^{\prime 37}$. Z tej perspektywy znaczące wydaje się też to, że realizowane w dwóch pierwszych dekadach po 1989 r. wielowymiarowe, pogłębione badania nad dziedziczeniem pozycji społecznej dotyczyły wyłącznie ubóstwa ${ }^{38}$ i były prowadzone poza głównym nurtem analiz strukturalnych.

Wątek jednostkowych i grupowych doświadczeń związanych z wędrówkami między pozycjami społecznymi oraz problem mechanizmów ograniczania dostępu do uprzywilejowanych pozycji społecznych pojawiają się w publikacjach polskich badaczek i badaczy wycinkowo lub jako jeden z kontekstów badań poświęconych innym zagadnieniom struktury społecznej. Większość tych analiz wydaje się też zresztą konsekwencją wzrostu zainteresowania wspomnianą wyżej kulturową koncepcją klas społecznych P. Bourdieu wśród młodszych generacji socjologów i antropologów po 2005 r. Na przykład w książce podsumowującej kilkuletnie badania nad klasowo zdeterminowanymi stylami życia pod redakcją Macieja Gduli i Przemysława Sadu-

34 Złożyły się na to zarówno polemiki z „oficjalnym” partyjnym marksizmem, jak i naukowe fascynacje liderów środowiska amerykańskimi badaniami nad hierarchiami społeczno-zawodowymi.

35 B.W. Mach, Pokolenie historycznej nadziei i codziennego ryzyka. Społeczne losy nastolatków z roku 1989, Wydawnictwo IFiS PAN, Warszawa 2003.

36 H. Domański, Struktura społeczna, op. cit.

37 Metafora inspirowana cytatem z Ewangelii: Każdemu bowiem, kto ma, będzie dodane, tak że nadmiar mieć będzie. Temu zaś, kto nie ma, zabiora nawet to, co ma (Mt 25,14-30). Zob. W. Wesołowski, K. Janicka, K.M. Słomczyński, op. cit.

38 Prowadzone głównie przez zespół pod kierunkiem Wielisławy Warzywody-Kruszyńskiej. 
ry ${ }^{39}$ znalazło się zestawienie pięciu biograficznych studiów przypadków, które łączy przede wszystkim fakt przemieszczania się respondentów między segmentami struktury społecznej ${ }^{40}$. Pojedyncze prace poświęcono specyfice doświadczenia awansu przez kobiety, a - z wyjątkiem badań nad systemem edukacji ${ }^{41}$ - niewiele wiadomo o uwikłaniu polityk publicznych w procesy utrwalania czy niwelowania międzygeneracyjnych barier społecznych z perspektywy równości szans i wyników.

Wydaje się, że najciekawsze obecnie wnioski z badań nad systemowymi kontekstami ruchliwości międzypokoleniowej można znaleźć poza klasyczną socjologią struktur społecznych, tj. w nowych nurtach socjologii historycznej, w warstwie metodologicznej inspirowanych podejściem studium przypadku i opartych na analizie zróżnicowanych źródeł archiwalnych, a także pogłębionych wywiadach. W ramach jednego z nich dokonuje się rewaluacji rzeczywistości PRL-u jako ustroju, w którym awans społeczny był elementem oficjalnej ideologii. Mieszczą się w tym nurcie prace tak różne jak: rekonstrukcja modernizacyjnych i emancypacyjnych funkcji socjalistycznego uniwersytetu autorstwa Agaty Zysiak ${ }^{42}$, praca Katarzyny Andrejuk o kobiecym doświadczeniu awansu społecznego w okresie Polski Ludowej, oparta na materiale biograficznym zgromadzonym w ramach badań POLPAN ${ }^{43}$, czy filozoficzno-historyczne rozważania Andrzeja Ledera ${ }^{44}$ na temat zbiorowego wyparcia społecznej rewolucji, której doświadczyło polskie społeczeństwo w latach 1939-1956.

W ramach drugiego nurtu, reprezentowanego przez Tomasza Zaryckiego i Rafała Smoczyńskiego, w perspektywie długiego trwania pokazuje się procesy odtwarzania się polskich elit szlachecko-inteligenckich przede wszystkim poprzez monopolizację dostępu do kapitału kulturowego, którego znaczenie dla procesów strukturalizacji społeczeństw Europy Środkowo-Wschodniej wydaje się nawet większe niż w krajach kapitalistycznego centrum ${ }^{45}$. W tej perspektywie warto zwrócić uwagę, że zarówno w polskiej debacie akademickiej, jak i w szerszej publicznej dyskusji nad ruchliwością społeczną i nierównościami społecznymi właściwie niesproblematyzowane pozostają doświadczenia osób pokonujących największe dystanse - z dołu drabiny społecznej do kulturalnych, ekonomicznych i politycznych elit ${ }^{46}$.

39 M. Gdula, P. Sadura, Style życia i porzadek klasowy w Polsce, Wydawnictwo Naukowe Scholar, Warszawa 2012.

40 Poza tym są to zróżnicowane biografie - zarówno pod względem płci, historycznych ram (PRL, transformacja ustrojowa), miejsca zamieszkania, jak i kierunków ruchliwości (biografia księdza, wojskowego, członka zarządu banku, osoby, która doznała degradacji ze statusu inteligenckiego).

41 P. Sadura, Państwo, szkoła, klasy, Wydawnictwo Krytyki Politycznej, Warszawa 2018.

42 A. Zysiak, Punkty za pochodzenie. Powojenna modernizacja i uniwersytet w robotniczym mieście, Nomos, Kraków 2016.

43 K. Andrejuk, Awans społeczny kobiet w czasach PRL. Dynamika struktury i sprawczości, „Przegląd Socjologiczny” 2016, t. 65, nr 3.

44 A. Leder, Prześniona rewolucja. Ćwiczenia z logiki historycznej, Wydawnictwo Krytyki Politycznej, Warszawa 2014.

45 T. Zarycki, R. Smoczyński, Totem inteligencki. Arystokracja, szlachta i ziemiaństwo w polskiej przestrzeni społecznej, Wydawnictwo Naukowe Scholar, Warszawa 2017.

46 Brytyjscy socjologowie przyjmujący perspektywę klasową, zwłaszcza ci należący do młodszego pokolenia, często otwarcie podejmują temat własnego np. robotniczego czy mniejszościowego pochodzenia jako czynnika uwrażliwiającego na wybrane aspekty społecznego awansu. Zob. P. Sadura, Walka klas czy zmiana pokoleniowa? Bourdieu we współczesnej socjologii brytyjskiej. Recenzja książki Jenny Thatcher, Nicoli Ingram, 
Także zjawisko deklasacji wciąż czeka na pełniejszy opis naukowy. Nieliczne istniejące opisy doświadczenia utraty pozycji społecznej w związku z transformacją systemową dotyczą jednak przede wszystkim wymiaru wewnątrzpokoleniowego i mają charakter etnograficzny ${ }^{47}$ lub stanowią element rekonstrukcji zbiorowej pamięci o prywatyzacji zakładów przemysłowych. Część tego typu opracowań, mających zresztą olbrzymie walory poznawcze, to prace reporterskie ${ }^{48}$.

\section{Analiza wzorów ruchliwości młodych dorosłych jako próba połączenia perspektyw badawczych ${ }^{49}$}

Wydaje się, że zarysowane powyżej podejścia mają niewiele punktów wspólnych. Dlatego zasadne jest osobne, choć skrótowe omówienie jedynej jak dotąd w polskiej socjologii próby połączenia perspektyw w badaniach ruchliwości międzypokoleniowej. Zrealizowane w latach 2006-2007 badanie ${ }^{50}$ zostało zaplanowane jako pogłębione porównawcze studium uwarunkowań i wzorów dziedziczenia niskiej pozycji społecznej i było częścią obejmującego osiem państw porównawczego projektu PROFIT (Policy Responses Overcoming Factors in the Intergenerational Transmission of Inequalities), prowadzonego pod kierunkiem badaczy z Uniwersytetu Łódzkiego i realizowanego dzięki grantowi z szóstego programu ramowego Komisji Europejskiej. Miało dostarczyć zarówno wiedzy na temat dziedziczenia niskiej pozycji społeczno-ekonomicznej w krajach o różnej specyfice społecznej, ekonomicznej oraz polityczno-instytucjonalnej ${ }^{51}$, jak i rekomendacji w zakresie efektywnych sposobów zapobiegania mu w przyszłości. Takie poznawczo-aplikacyjne ukierunkowanie projektu można jednoznacznie powiązać z dominującym w europejskich politykach publicznych postrzeganiem awansu społecznego jako najskuteczniejszego instrumentu walki z dziedzicznym ubóstwem. Projekt nie odbiegał też zasadniczo od weberowskiej perspektywy, jeśli chodzi o pomiar pozycji społecznej za pomocą zmiennych takich jak wykształcenie i zawód.

Przyjęto szereg założeń sytuujących projekt poza głównym nurtem badań nad ruchliwością społeczną ${ }^{52}$. Założono np., że procesy międzygeneracyjnej ruchliwości są uwarunkowane nie

Ciarana Burke'a i Jessie Abrahams (red.), Bourdieu: The Next Generation. The development of Bourdieu's intellectual heritage in contemporary UK Sociology, "Studia Socjologiczno-Polityczne” 2016, t. 5, nr 1-2. Z kolei autobiograficzna opowieść francuskiego socjologa i filozofa Didiera Eribona stała się międzynarodowym bestsellerem. Zob. D. Eribon, Powrót do Reims, Karakter, Kraków 2019. W Polsce wyjątkowym przykładem tego typu refleksji wydaje się film dokumentalny Joanny Warechy PRL. Obrazy (TVP 2018), osnuty wokół napięcia pomiędzy biograficznym doświadczeniem awansu autorki a postępującą degradacją wsi popegeerowskich i deklasacją ich mieszkańców.

47 T. Rakowski, Łowcy zbieracze, praktycy niemocy, Słowo Obraz Terytoria, Gdańsk 2009.

48 M. Madejska, Aleja włókniarek, Wydawnictwo Czarne, Wołowiec 2018.

49 Niniejszy podrozdział został oparty na fragmentach książki: M. Rek-Woźniak, Młodzi dorośli. Wzory ruchliwości społecznej w okresie transformacji systemowej, Wydawnictwo Uniwersytetu Łódzkiego, Łódź 2016, https://doi. org/10.18778/7969-984-1.

50 Regulacja Komisji Europejskiej nr 16/2004 z 6 stycznia 2004 r.

51 Poza Polską były to: Bułgaria, Estonia, Finlandia, Litwa, Niemcy, Wielka Brytania i Włochy.

52 W. Warzywoda-Kruszyńska, E. Rokicka, Projekt PROFIT. Główne założenia i metodologia badania, „Polityka Społeczna" 2008, numer specjalny. 
tylko makrostrukturalnie, ale także dostępem do konkretnych zasobów społecznych, ekonomicznych i instytucjonalnych w miejscu dorastania. Przyjęto także, że mimo pewnej unifikacji kulturowych wzorów awansu społecznego aspiracje konkretnych ludzi wciąż powstają w relacji do lokalnego kontekstu. Dlatego w przeciwieństwie do klasycznych badań ruchliwości społecznej, realizowanych metodami kwestionariuszowymi na wielotysięcznych próbach ogólnokrajowych, tu przyjęto strategię charakterystyczną dla studiów przypadku, w których od statystycznej reprezentatywności i możliwości generalizacji wniosków bardziej istotna jest pogłębiona, wielowymiarowa charakterystyka stosunkowo wąsko zdefiniowanego problemu. Zasadnicza część materiału empirycznego została zebrana w celowo dobranym mieście powiatowym, które doświadczyło skutków gwałtownej deindustrializacji w latach 90. Ze względu na interdyscyplinarny charakter badania, lokujący je na pograniczu socjologii i nauk o politykach publicznych, w korpusie danych znalazły się informacje urzędowe dotyczące lokalnego rynku pracy, instytucji edukacyjnych i pomocowych, a także dane wytworzone podczas wywiadów z lokalną elitą (władzami politycznymi i osobami zarządzającymi instytucjami) oraz osobami pracującymi w tych instytucjach „na pierwszej linii” (nauczycielami, pracownikami socjalnymi, kuratorami, doradcami zawodowymi).

Centralną dla badania kategorią społeczną uczyniono tzw. młodych dorosłych, tj. osoby w wieku od 25 do 29 lat, które wszystkie decyzje istotne w kontekście procesu zajmowania pozycji społecznej (edukacyjne, zawodowe i osobiste) podejmowały już po 1989 r. Ich strategie życiowe mogły więc być budowane w konfrontacji z gwałtownymi przemianami lokalnego rynku pracy, a także z przebudową lokalnego zaplecza instytucjonalnego. Pierwszy etap analiz zakładał statystyczny opis strukturalnych przesunięć w oparciu o dane sondażowe (743 obserwacje). Na jego podstawie wyłoniono podkategorię kobiet i mężczyzn wywodzących się z rodzin najniżej ulokowanych w strukturze społecznej i przeprowadzono z nimi 40 pogłębionych wywiadów, pozwalających na szczegółową rekonstrukcję biografii edukacyjnych, zawodowych i osobistych. Ich analiza pozwoliła zidentyfikować sześć wzorów biografii (tabela 1), odpowiadających trzem kierunkom wędrówek pozycyjnych: awansu, stagnacji i degradacji, charakteryzującym się zróżnicowanym układem nie tylko zdarzeń, ale również sposobów ich przeżywania i relacjonowania.

Jednocześnie wszystkim wzorom towarzyszyły rozmaite ambiwalentne lub trudne przeżycia. Niezależnie od poziomu osiągnięć i wpływu różnych czynników zewnętrznych na przebieg życia badanych prezentowali oni indywidualistyczne nastawienie wobec własnych biografii, co można interpretować jako wyraz uwewnętrznienia kodu kulturowego polskiej transformacji, eksponującego wyłączną odpowiedzialność jednostki za to, jak toczą się jej losy. Szczególnie widoczne było to w kontekście czterech zidentyfikowanych przypadków międzygeneracyjnej degradacji. W tych historiach najpełniej ujawniała się słabość nie tylko indywidualnych zasobów badanych, ale i społecznych sieci - zarówno rodzinnych, jak i instytucjonalnych. Jednocześnie charakteryzował je specyficzny splot przeświadczeń o osobistej odpowiedzialności i fatalizmu, związanego z poczuciem permanentnej tymczasowości. W większości biografii awansu ujawniały się z kolei napięcia i frustracja związane z tzw. rozbieżnością cech położenia społecznego (typ pracy i dochody niezgodne z poziomem kwalifikacji), wzmacnianą przez złą sytuację na lokalnym rynku pracy. Część osób reprodukujących pozycję rodziców charakteryzowała konieczność podejmo- 


\section{Tabela 1. Typologia biografii młodych dorosłych z rodzin o niskim statusie społeczno-ekono- micznym}

\begin{tabular}{|c|c|c|c|c|c|c|}
\hline Typ & Wariant & $\begin{array}{l}\text { Spójność } \\
\text { wymiarów } \\
\text { położenia } \\
\text { społecz- } \\
\text { nego }\end{array}$ & $\begin{array}{c}\text { Płynność prze- } \\
\text { biegu życia, } \\
\text { kolejność faz }\end{array}$ & $\begin{array}{c}\text { Zagrożenia dla } \\
\text { ciągłości prze- } \\
\text { biegu życia }\end{array}$ & $\begin{array}{l}\text { Interwencje } \\
\text { w przebieg } \\
\text { życia }\end{array}$ & $\begin{array}{c}\text { Subiek- } \\
\text { tywna } \\
\text { ocena } \\
\text { położenia } \\
\text { względem } \\
\text { rodziców }\end{array}$ \\
\hline \multirow{2}{*}{ 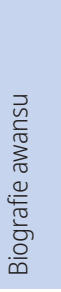 } & zwycięzca & tak & tak & $\begin{array}{l}\text { brak lub pojawia- } \\
\text { jące się w życiu } \\
\text { dorosłym }\end{array}$ & $\begin{array}{l}\text { wysokie zaanga- } \\
\text { żowanie rodziny } \\
\text { w osiąganie } \\
\text { awansu }\end{array}$ & awans \\
\hline & w pół drogi & nie & $\begin{array}{l}\text { wydłużone, } \\
\text { nieciągłe kariery } \\
\text { edukacyjne } \\
\text { i zawodowe }\end{array}$ & $\begin{array}{l}\text { pojawiające się } \\
\text { w okresie nasto- } \\
\text { letnim }\end{array}$ & $\begin{array}{l}\text { pogorszenie } \\
\text { sytuacji ekono- } \\
\text { micznej rodziny } \\
\text { pochodzenia }\end{array}$ & $\begin{array}{l}\text { ambiwalen- } \\
\text { cja/ } \\
\text { degradacja }\end{array}$ \\
\hline \multirow[b]{2}{*}{ 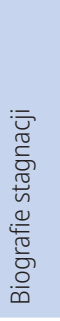 } & reprodukcja & tak & tak & $\begin{array}{l}\text { pojawiające się } \\
\text { w dorosłym życiu }\end{array}$ & $\begin{array}{l}\text { niskie zaangażo- } \\
\text { wanie rodziców, } \\
\text { niewidzialni dla } \\
\text { instytucji }\end{array}$ & $\begin{array}{l}\text { stagnacja/ } \\
\text { awans }\end{array}$ \\
\hline & Syzyf & nie & $\begin{array}{l}\text { nieudane próby } \\
\text { kontynuowa- } \\
\text { nia edukacji, } \\
\text { nieciągłe kariery } \\
\text { zawodowe }\end{array}$ & $\begin{array}{l}\text { pojawiające się } \\
\text { w okresie nasto- } \\
\text { letnim i dorosłym } \\
\text { życiu }\end{array}$ & $\begin{array}{l}\text { niskie zaangażo- } \\
\text { wanie rodziców, } \\
\text { zdarzenia loso- } \\
\text { we, pauperyzacja } \\
\text { rodziny }\end{array}$ & degradacja \\
\hline \multirow{2}{*}{$\begin{array}{l}: \overline{0} \\
\frac{\pi}{0} \\
\frac{0}{0} \\
\frac{0}{0} \\
\frac{0}{0} \\
\frac{0}{0} \\
\frac{0}{5} \\
\frac{0}{0}\end{array}$} & Hiob & tak & $\begin{array}{l}\text { przerwane karie- } \\
\text { ry edukacyjne, } \\
\text { nieciągłości ka- } \\
\text { rier zawodowych }\end{array}$ & $\begin{array}{l}\text { „trajektoria } \\
\text { cierpienia” }\end{array}$ & $\begin{array}{l}\text { dysfunkcje } \\
\text { w rodzinie, } \\
\text { nieskuteczne } \\
\text { interwencje } \\
\text { instytucjonalne }\end{array}$ & degradacja \\
\hline & $\begin{array}{l}\text { syn marno- } \\
\text { trawny }\end{array}$ & tak & $\begin{array}{l}\text { przerwane karie- } \\
\text { ry edukacyjne, } \\
\text { nieciągłości ka- } \\
\text { rier zawodowych }\end{array}$ & $\begin{array}{l}\text { rozwój kariery } \\
\text { dewiacyjnej }\end{array}$ & $\begin{array}{l}\text { pauperyzacja ro- } \\
\text { dziny, nieskutecz- } \\
\text { ne interwencje } \\
\text { instytucjonalne }\end{array}$ & degradacja \\
\hline
\end{tabular}

Źródło: M. Rek-Woźniak, Młodzi dorośli. Wzory ruchliwości społecznej w okresie transformacji systemowej, Wydawnictwo Uniwersytetu Łódzkiego, Łódź 2016, s. 240.

wania ciągłej walki o utrzymanie się na rynku pracy i wdrażania nierzadko skomplikowanych strategii mających na celu zwiększenie poczucia bezpieczeństwa. Jednocześnie borykali się oni z ciągłym poczuciem życiowej porażki.

Powyższy wynik - wykraczający poza założone cele projektu (tj. identyfikację czynników utrudniających i ułatwiających awans społeczny) - nie uprawnia do formułowania mocnych wniosków czy uogólnień. Jego dalsza, bardziej pogłębiona interpretacja była zresztą utrudniona ze względu na niedowartościowanie wątków relacyjnych i tożsamościowych na etapie konceptualizacji problematyki badania. Jednocześnie jednak uzyskanie tego typu materiału prawdopodobnie nie byłoby możliwe, gdyby zespół badawczy nie spróbował przynajmniej częściowo wyjść poza teoretyczno-metodologiczne kanony analiz strukturalnych. 
Powyższe doświadczenie wydaje się przemawiać nie tylko za potrzebą bardziej systematycznych i pogłębionych badań doświadczeń ruchliwości międzypokoleniowej w polskiej rzeczywistości (po)transformacyjnej, ale też za poszerzaniem perspektyw analitycznych i powrotem do podstawowych pytań o rolę ruchliwości w życiu indywidualnym i zbiorowym. Zachęca także do zawieszania milczących założeń na temat „dyskursu celebracyjnego”, skupionego wokół idei równości szans.

\section{Podsumowanie}

Ruchliwość międzypokoleniowa jest zjawiskiem wielowymiarowym i skomplikowanym - w wymiarze zarówno jednostkowym, jak i społecznym. Jej operacyjne definicje, tworzone na potrzeby badań społecznych, z konieczności koncentrują się jedynie na wybranych jego aspektach i konsekwencjach. W polskich badaniach po 1989 r. najsilniejsze okazały się te nurty, w których przedmiotem zainteresowania były przede wszystkim otwartość struktury społecznej i szanse awansu społecznego. Takie ukierunkowanie prac badawczych i debaty publicznej wydaje się w pewnym sensie zrozumiałe, zwłaszcza w okresie gwałtownych przekształceń porządku społecznego. Jednak wciąż nieliczne prace skupione na relacyjnych aspektach i indywidualnym przeżywaniu pozycyjnych przemieszczeń po 1989 r. wskazują na niejednoznaczne konsekwencje funkcjonowania w społeczeństwie, w którym indywidualny awans stanowi właściwie jedyną szansę na poprawę jakości i warunków życia, a także źródło osobistej godności. Z pewnością warto tego typu badania prowadzić na szerszą skalę i za pomocą zróżnicowanego instrumentarium metodologicznego tak by opisać spektrum przesunięć w strukturze społecznej, a także ich ekonomiczne, kulturowe i polityczne konteksty. Potrzebne wydaje się też aktualizowanie takiej wiedzy w warunkach krzepnącego ładu potransformacyjnego i polaryzującej się struktury społecznej.

Jeśli powyższym postulatom miałyby towarzyszyć cele praktyczne, wiązałyby się z nadzieją na korektę debaty zarówno naukowej, jak i publicznej oraz dowartościowanie w nich zasady „równości wyniku”.

\section{Bibliografia}

Andrejuk K., Awans społeczny kobiet w czasach PRL. Dynamika struktury i sprawczości, „Przegląd Socjologiczny” 2016, t. 65, $\mathrm{nr} 3$.

Bourdieu P., Dystynkcja. Społeczna krytyka władzy sadzenia, Wydawnictwo Naukowe Scholar, Warszawa 2005. Bourdieu P., La Noblesse d'État. Grandes écoles et esprit de corps, Minuit, Paris 1993.

Bourdieu P., Passeron J.C., Reprodukcja. Elementy teorii systemu nauczania, Wydawnictwo Naukowe PWN, Warszawa 2006.

Chałasiński J., Awans pokolenia, Ludowa Spółdzielnia Wydawnicza, Warszawa 1964.

Chałasiński J., Drogi awansu społecznego robotnika: studium oparte na autobiografiach robotników, Ludowa Spółdzielnia Wydawnicza, Warszawa 1979.

Clark G., The Son Also Rises. Surnames and the History of Social Mobility, Princeton University Press, Princeton 2014, https://doi.org/10.1515/9781400851096. 
Davis K., Moore W.E., O niektórych zasadach uwarstwienia [w:] Socjologia. Lektury, Znak, Kraków 2005.

Domański H., O ruchliwości społecznej w Polsce, Wydawnictwo IFiS PAN, Warszawa 2004.

Domański H., Struktura społeczna, Wydawnictwo Naukowe Scholar, Warszawa 2007.

Eribon D., Powrót do Reims, Karakter, Kraków 2019.

Erikson R., Goldthorpe J.H., The Constant Flux. A Study of Class Mobility in Industrial Societies, Clarendon Press, Oxford 1992.

Friedman S., The Price of the Ticket: Rethinking the Experience of Social Mobility, "Sociology” 2014, vol. 48, no. 2, https://doi.org/10.1177/0038038513490355.

Friedman S., Laurison D., The Class Ceiling: Why it Pays to be Privileged, Bristol University Press, Bristol 2019, https://doi.org/10.1590/s0104-71832019000300018.

Gdula M., Sadura P., Style życia i porzadek klasowy w Polsce, Wydawnictwo Naukowe Scholar, Warszawa 2012.

Goldthorpe J.H., Jackson M., Intergenerational class mobility in contemporary Britain: political concerns and empirical findings. British Journal of Sociology, "The British Journal of Sociology” 2008, vol. 58, no. 4, https://doi. org/10.1111/j.1468-4446.2007.00165.x.

Goldthorpe J.H., Llewellyn C., The Experience of Social Mobility [w:] Social Mobility and Class Structure in Modern Britain, Clarendon Press, Oxford (UK) 1980.

Grusky D.B., Weeden K.A., Does the Sociological Approach to Studying Social Mobility Have a Future [w:] Mobility and Inequality: Frontiers of Research From Sociology and Economics, Stanford University Press, Stanford 2006.

Hertel F.F., Groh-Samberg O., The Relation between Inequality and Intergenerational Class Mobility in 39 Countries, „American Sociological Review” 2019, vol. 84, no. 6, https://doi.org/10.1177/0003122419885094.

Lahire B., L'Homme pluriel. Les ressorts de l'action, Hachette, Paris 2007.

Leder A., Prześniona rewolucja. Ćwiczenia z logiki historycznej, Wydawnictwo Krytyki Politycznej, Warszawa 2014.

Lister A., The "Mirage” of Social Justice: Hayek Against (and For) Rawls, "Critical Review” 2013, vol. 25, no. 3-4, https://doi.org/10.1080/08913811.2013.853859.

Mach B.W., Pokolenie historycznej nadziei i codziennego ryzyka. Społeczne losy nastolatków z roku 1989, Wydawnictwo IFiS PAN, Warszawa 2003.

Madejska M., Aleja włókniarek, Wydawnictwo Czarne, Wołowiec 2018.

OECD, A Broken Social Elevator? How to Promote Social Mobility, OECD Publishing, 2018, https://doi. org/10.1787/9789264301085-en.

Ossowski S., Ruchliwość społeczna jako wynik rewolucji społecznej [w:] Dzieła, t. 5, Z zagadnień struktury społecznej, PWN, Warszawa 1968.

Ost D., Stuck in the Past and the Future. Class Analysis in Postcommunist Poland, "East European Politics and Societies" 2015, vol. 29, no. 3, https://doi.org/10.1177/0888325415602058.

Payne G., A New Social Mobility? The political redefinition of a sociological problem, "Contemporary Social Science” 2012, vol. 7, no. 1, https://doi.org/10.1080/21582041.2011.652360.

Rakowski T., Łowcy zbieracze, praktycy niemocy, Słowo Obraz Terytoria, Gdańsk 2009.

Rawls J., Teoria sprawiedliwości, Wydawnictwo Naukowe PWN, Warszawa 1994.

Rek-Woźniak M., Młodzi dorośli. Wzory ruchliwości społecznej w okresie transformacji systemowej, Wydawnictwo Uniwersytetu Łódzkiego, Łódź 2016, https://doi.org/10.18778/7969-984-1.

Sadura P., Państwo, szkoła, klasy, Wydawnictwo Krytyki Politycznej, Warszawa 2018. 
Sadura P., Walka klas czy zmiana pokoleniowa? Bourdieu we wspótczesnej socjologii brytyjskiej. Recenzja ksiq̨żki Jenny Thatcher, Nicoli Ingram, Ciarana Burke'a i Jessie Abrahams (red.), Bourdieu: The Next Generation. The development of Bourdieu's intellectual heritage in contemporary UK Sociology , "Studia Socjologiczno-Polityczne” 2016, t. 5, nr 1-2.

Warzywoda-Kruszyńska W., Rokicka E., Projekt PROFIT. Główne założenia i metodologia badania, „Polityka Spoteczna" 2008, numer specjalny.

Weber M., Gospodarka i społeczeństwo, Wydawnictwo Naukowe PWN, Warszawa 2002.

Wesołowski W., Klasy, warstwy, władza, PWN, Warszawa 1974.

Wesołowski W., Janicka K., Słomczyński K.M., Struktutralizacja społeczeństwa polskiego. Ewolucja paradygmatu, Wydawnictwo IFiS PAN, Warszawa 2017.

Wesołowski W., Mach B.W., Systemowe funkcje ruchliwości społecznej w Polsce, IFiS PAN, Warszawa 1986.

White S., Równość, Sic!, Warszawa.

Woźniak W., Nierówności społeczne w polskim dyskursie politycznym, Wydawnictwo Naukowe Scholar, Warszawa 2012.

Woźniak W., Użycie i nadużycie nauk społecznych. Przypadek merytokracji [w:] Wiedza, władza, ideologia. O społecznej funkcji uniwersytetu w społeczeństwie rynkowym, Wydawnictwo Naukowe Scholar, Warszawa 2012.

Zagórski K., Rozwój, struktura i ruchliwość społeczna, PWN, Warszawa 1978.

Zarycki T., Smoczyński R., Totem inteligencki. Arystokracja, szlachta i ziemiaństwo w polskiej przestrzeni społecznej, Wydawnictwo Naukowe Scholar, Warszawa 2017.

Zysiak A., Punkty za pochodzenie. Powojenna modernizacja i uniwersytet w robotniczym mieście, Nomos, Kraków 2016. 